\title{
Legal Education Reform: Simulating Complex Litigation Practice in an Advanced Legal Writing Course
}

\author{
Patricia Grande Montana*
}

Zusammenfassung: Die Didaktik der Rechtswissenschaft ist einerseits eng mit einem spezifischen nationalen Wissenschaftsverständnis sowie dem - trotz Europäisierung und Globalisierung des Rechts - im Mittelpunkt der Ausbildung stehenden nationalen Recht verknüpft. Andererseits sind vielfältige Grundfragen eines professionsorientierten Studiums rechts- und ausbildungssystemübergreifend. Die Befassung mit Unterschieden und deren Ursachen kann den Blick für Spezifika schärfen, aber auch Anregungspotential für Neuerungen bieten. Im Sinne eines „Blickes über den Tellerrand “ wird die Zeitschrift für Didaktik der Rechtswissenschaft in unregelmäßigen Abständen Beiträge aus dem Ausland, insbesondere dem anglo-amerikanischen Raum, veröffentlichen. Den Anfang macht der folgende Beitrag von Patricia Montana. In ihm geht die Autorin von einem Strukturwandel des juristischen Arbeitsmarktes in den USA aus. Unter anderem deshalb finden derzeit intensive Debatten über die Praxisorientierung des dreijährigen Studiums an den Law Schools statt. Vor diesem Hintergrund widmet sich Montana einem in den USA gängigen, in Deutschland jedoch nach wie vor seltenen Lehrangebot, den Kursen zum legal research and writing sowie deren Verbesserungspotentialen. Die Zitierweise entspricht den USamerikanischen Standards. - Die Herausgeber.

\section{A. Introduction}

With the decline in law jobs, rising tuition, and mounting levels of student debt, legal education has been under increasing attack. One of the major criticisms is that it fails to adequately prepare students for the practice of law. Though this criticism has received more attention as of late, it is far from new. In fact, back in 2007, two very influential institutes published reports that concluded that law schools must devote more attention and resources to helping students develop the professional skills they will need in practice. The Carnegie Foundation for the Advancement of Teaching published its report, "Educating Lawyers: Preparation for the Profession of Law", 1 and the Clinical Legal Education Association published its study, "Best Practices for Legal Education". ${ }^{2}$ The general sentiment of both reports was that law graduates "lack the minimum competencies required to provide effective and responsible legal services." 3 Thus, the reports challenged law schools to unite formal knowledge

* Professor of Legal Writing, Director of Street Law: Legal Education in the Community Program, St. John's University School of Law.

1 William M. Sullivan et al., Educating Lawyers: Preparation for the Profession of Law (2007) ("Carnegie Report”).

2 Roy Stuckey and Others, Best Practices for Legal Education: A Vision and A Road Map (2007) ("Best Practices Report"). "It is generally conceded that most law school graduates are not as prepared for law practice as they could be or should be. Law schools can do much better." Id. at 7.

3 Stuckey, supra n. 2, at 2. 
with the experience of practice, ${ }^{4}$ finding that " $[\mathrm{s}]$ tudents need a dynamic curriculum that moves them back and forth between understanding and enactment [and] experience and analysis." ${ }^{5}$

Lawyers, judges, academics, and even non-lawyers have expressed these same sentiments over the years too. ${ }^{6}$ Naturally, the complaints over how unprepared law school graduates are for the practice of law have intensified recently, as legal employment opportunities continue to shrink and law school tuition continues to grow. ${ }^{7}$ Among the most common complaints is that law graduates do not research or write well. ${ }^{8}$ Nor do they understand the realities or demands of a law practice. ${ }^{9}$ While legal employers might have trained new attorneys in these areas in the past, they are no longer willing or able to invest in such practical skills training. ${ }^{10}$ Instead, they expect their new hires to be "practice ready" - that is, capable of immediately mastering and explaining to their clients, both orally and in writing, the substantive legal issues and rules relevant to their problem. ${ }^{11}$ This new landscape has forced law schools to rethink how they teach and train their students so that they may graduate with the core competencies expected of a "practice ready" attorney. At the same time, it has led critics and others to call for real and immediate changes in legal education. ${ }^{12}$

In different ways, law schools already have begun responding to the pressures of the new legal market and implementing the recommendations of the Carnegie and Best Practices reports. They are experimenting with ways to infuse more practical legal problem-solving into their curricula and improving the way they provide skills training. Some responses have included increasing clinical and experiential learning opportunities, using more collaborative teaching, and incorporating multi-disciplinary

4 Id. at 97-100; Sullivan et al., supra n. 1, at 12-13, 194-97.

5 Sullivan et al., supra n. 1, at 197.

6 See, e.g., David Segal, Is Law School a Losing Game? N.Y. Times, Jan. 9, 2011, at BU1; David Segal, What They Don't Teach Law Students: Lawyering, N.Y. Times, Nov. 20, 2001, at A1.

7 See David Segal, Is Law School a Losing Game? N.Y. Times, Jan. 9, 2011, at BU1; see also Brian Z. Tamanaha, The Mismatched Economics of Legal Education, 85 N.Y. St. B.A. J., Sept. 2013, at 14, 15.

8 Aliza B. Kaplan \& Kathleen Darvil, Think [and Practice] Like a Lawyer: Legal Research for the New Millennials, 8 Legal Comm. and Rhetoric: JALWD 153, 157 (2011).

9 Rachel J. Littman, Training Lawyers for the Real World Part One, 82 N.Y. St. B. J., Sept. 2010, at 20, 23 ("New attorneys are expensive, inefficient, unable to write, and lack the basic business sense and professional skills necessary to function immediately as value-adding, practicing attorneys.”).

10 Kaplan \& Darvil, supra n. 8, at 157; William D. Henderson, A Blueprint for Change, 40 Pepp. L. Rev. 461, 462 (2013).

11 A practice-ready attorney is someone who "possesses a deep knowledge of the law, and knows how to apply this knowledge to solve her client's legal problem.” Sherri Lee Keene, One Small Step for Legal Writing, One Giant Leap for Legal Education: Making the Case for More Writing Opportunities in the 'Practice-Ready' Law School Curriculum, 65 Mercer L. Rev. (arguing that legal educators should make "better use" of legal writing practice opportunities "to expedite the professional development of those new to the practice of law").

12 See, e.g., Ethan Bronner, A Call for Drastic Changes in Educating New Lawyers, N.Y. Times, Feb. 11, 2013, at A11. 
techniques. ${ }^{13}$ Though these types of changes are certainly needed and ought to be pursued, law schools should also consider leveraging an existing curricular strength: their advanced legal writing courses. Most law schools offer a breadth of advanced legal writing courses intended for students to build on the foundational principles learned in their first-year legal writing program and to develop an expertise in complex legal research, analysis, and practice-writing. Therefore, unlike doctrinal courses, even those that might have a writing component, advanced legal writing courses are designed to resemble and teach real-world practice. With the right planning, they can serve as an ideal place to simulate a multifaceted litigation practice and allow students to work as lawyers do.

Thus, this Article proposes that law school education reform should examine the value of established advanced legal writing courses. They offer a very simple and inexpensive way to develop a student's analytical, research, writing, and presentation skills, and therefore present a perfect opportunity to answer the critics' call for more "practice ready" lawyers. ${ }^{14}$

Specifically, the Article first discusses the landscape of today's legal market. It examines how the downturn in the economy has reshaped legal practice and, as a result, put pressure on law schools to graduate more competent professionals. Next, it addresses the legal academy's response to market pressures and the public's increased criticism over traditional law school instruction. Finally, it explores how the design and subject matter of an advanced legal writing course can teach students practical proficiency in the skills needed for practice.

Using my own advanced legal writing course, Drafting: Federal Civil Practice, as a model, the Article illustrates how a course centered on a single litigation involving a complicated statute and a well-developed set of facts can easily simulate the realities of law practice. It not only teaches complex legal analysis and advanced persuasive writing, but it also exposes students to a host of litigation documents. Both the design and subject matter motivates students to learn and apply core legal analysis and writing skills in a rigorous, client-centered environment. Among other things, students learn to problem-solve, address factual and legal indeterminacy, and manage client expectations - all skills of a "practice ready" lawyer. In this way, law schools can teach students the "skills and inclinations, along with the ethical standards, social roles, and responsibilities that mark" a professional lawyer using resources presently available to them. ${ }^{15}$

13 Rachel J. Littman, Training Lawyers for the Real World Part Two, 82 N.Y. St. B. J., Oct. 2010, at 31, 31-32.

14 " $[\mathrm{N}]$ ot all experiential, practice-oriented initiatives require additional costly investments. Much can be accomplished with existing resources through case histories, problems, simulations, cooperative projects, and interdisciplinary collaboration." Deborah L. Rhode, Legal Education: Rethinking The Problem, Reimagining Reforms, 40 Pepp. L. Rev. 437, 449 (2013).

15 Sullivan et al., supra n. 1, at 28. 


\section{B. The Old Legal Market}

The economic recession that began in December $2007^{16}$ has radically changed the legal job market. Hit hardest were the large Wall Street law firms and other large and mid-sized law firms whose business models were based on a pyramid structure. Under a typical pyramid structure, there would be a large number of associates at the bottom of the pyramid and a small number of equity partners at the top. In this way, law firms could maintain a leveraged ratio of associates to partners. ${ }^{17}$ Partners, predominately the non-equity partners, would bring in the lion's share of the profits and, for every new associate hired, profits would increase. ${ }^{18}$ Young lawyers could move up in the ranks, but only a select few would be promoted to partner; those who did not would be pushed out. ${ }^{19}$ This practice ensured that law firms preserved their high profits. ${ }^{20}$ Yet it also meant that law firms had to continuously hire a large number of new associates to replace those attorneys who had vacated the bottom of the pyramid. ${ }^{21}$

Prior to the recession, law firms grew exponentially under this model, especially because the number of associates promoted typically exceeded the number of partners who would leave or retire. ${ }^{22}$ As a result, the pyramid structure resulted in a wealth of job opportunities for new law school graduates, who were needed to fill the bottom of the pyramid. Eventually, law firms found themselves competing for top graduates, offering "ever-expanding associate salaries and lavish summer programs." 23 As a consequence, they were "in a poor position to demand that their new hires possess training in practical skills." ${ }^{24}$ It did not seem to matter anyway, as the "work that generally occupied new associates at the bottom level of the pyramid did not require extensive practical training." 25 "Th[e] work typically included wading through large discovery requests in complex litigation, document review, and basic research and writing." 26

The rapid growth of the large and mid-sized law firms had a "trickle-down effect" on smaller firms, government agencies, and public interest organizations. ${ }^{27}$ In response to what had become essentially a "recruiting frenzy," they "had to increase

16 Press Release, Nat'l Bureau of Econ. Research, Determination of the December 2007 Peak in Economic Activity (Dec. 11, 2008), available at http://www.nber.org/dec2008.pdf (9.11.2014).

17 Daniel Thies, Rethinking Legal Education in Hard Times: The Recession, Practical Legal Education and the New Job Market, 59 J. of Legal Educ. 598, 600 (2009-2010).

18 Id., at 600.

19 Id.

20 Id.

21 Id.

22 Id.

23 Id. at 601.

24 Id. at 602.

25 Id.

26 Id.

27 Id. at 601, n.14. 
their recruiting efforts as well, thus limiting their ability to demand more practical skills of their job applicants." 28

In short, legal employers, regardless of type or size, had diminished expectations about the skills of the young attorneys they would hire. There was no expectation that new law graduates would arrive to work knowing how to do the complex tasks of a practicing attorney. To the extent that a legal employer needed or wanted their young attorneys to know and do more, they would train them. In this growing market, legal employers were profitable and had the resources and staff to train summer associates and their younger associates, as well as offer continuing education courses for the more senior ones. They would run time-intensive and costly "boot camps," in-house skills training, and other programs and retreats. ${ }^{29}$ At the time, clients, who were also prospering, were generally accepting of this trend, as law firms would often pass the cost of training on to them. ${ }^{30}$

Not surprisingly, this trend influenced how law schools prepared students for practice. Law schools had little incentive to incorporate and emphasize practical skills training. ${ }^{31}$ Since law graduates would learn practical skills on the job, law schools instead focused largely on teaching theory and doctrine and engaging students in the Socratic dialogue. In other words, "[t] he structure of the job market thus allowed schools to put skills training on the backburner." 32

\section{The New Legal Market}

The recession has had a crushing effect on the legal market. With a decline in the demand for legal services and reductions in client-spending, the traditional pyramid structure is no longer sustainable. ${ }^{33} \mathrm{Law}$ firms have had to make significant cutbacks, including reducing the number of attorneys they employ. ${ }^{34}$ "Associates have been laid off, partners nudged out the door and recruitment programs have been scaled back or eliminated" altogether. ${ }^{35}$ Law firms have shifted as much work as possible to lower paid staff attorneys or contract attorneys, thereby obviating the need for large numbers of associates to fill the bottom of the pyramid. ${ }^{36}$ They have also turned to non-traditional solutions to save costs, such as the outsourcing of research over

Id. at 601-02, n.14.

29 Littman, supra. n. 9, at 22.

30 James E. Moliterno, The Future of Legal Education Reform, 40 Pepp. L. Rev. 423, 435 (2013).

31 Thies, supra n. 17, at 602-03 ("Because law firms did not expect students to bring these skills with them to their first job, failure to acquire them in law school was not fatal to a student's job prospects.").

32 Id. at 603.

33 Henderson, supra n. 10, at 462.

34 Segal, supra n. 7, at BU1.

35 Id.

36 Id. 
the internet. ${ }^{37}$ These changes have, in turn, resulted in widespread attorney unemployment and increased self-employment. ${ }^{38}$

The fact that clients are also struggling financially and no longer willing to pay the high costs of training junior attorneys has only compounded the problem. ${ }^{39} \mathrm{Clients}$ do not want inexperienced attorneys working on their accounts, particularly when there is "a plentitude of skilled senior lawyers who are unable or unwilling to retire." 40 In fact, some clients will outright refuse to pay their bills if they know that they have been charged for work done by a recent law school graduate or an otherwise junior attorney. ${ }^{41}$ For decades, they had underwritten the training of new lawyers - paying them to learn on the job. ${ }^{42}$ "But the downturn in the economy, and long-running efforts to rethink legal fees, have prompted more and more of those clients to send a simple message to law firms: Teach new hires on your own dime." 43

Therefore, the shrinking job market for entry level law jobs has resulted in "[a]n economic transfer" 44 with law firms and other legal employers pressuring law schools to assume more of the practical training. In addition, unlike before, legal employers are placing "a premium on job candidates with practical skills - those on whom they will not have to spend time and money before they are ready to practice." 45 To meet these new demands, law schools have had to find ways to infuse more practical skills training into their curricula.

Even with these types of changes, it is unlikely that the legal job market will improve quickly enough to see immediate marked improvements in employment opportunities for new attorneys. ${ }^{46}$ Though the recession ended in June 2009, the economy has far from recovered. ${ }^{47}$ The economic conditions are still not favorable, nor has the economy returned to its normal operating capacity. ${ }^{48}$ To make matters worse, there has been no indication that the legal market will return to its pre-recession form. ${ }^{49}$

37 Bronner, supra n. 12, at A11; Henderson, supra n. 10, at 479 (explaining how new entrants into the legal services market now offer legal inputs and legal products to law firms, thereby "reducing the need for expensive, artisan-trained lawyers").

38 Keene, supra n. 11.

39 Henderson, supra n. 10, at 462; Kaplan \& Darvil, supra n. 8, at 157.

40 Henderson, supra n. 10, at 462.

41 David Segal, What They Don't Teach Law Students: Lawyering, N.Y. Times, Nov. 20, 2001, at A1; Keene, supra n. 11.

42 Segal, supra n. 41, at A1.

43 Id.

44 Moliterno, supra. n. 30, at 435.

45 Thies, supra n. 17 , at 599.

46 Keene, supra n. 11.

47 Press Release, Nat'l Bureau of Econ. Research, Bus. Cycle Dating Comm. (Sept. 20, 2010), available at http://www.nber.org/cycles/sept2010.pdf (9.11.2014).

48 Id.

49 Keene, supra n. 11 ("Sadly, many doubt that the legal market will recover anytime soon, and some observers predict that the very structure of legal practice has been changed forever."). 


\section{Legal Education's Response}

Law schools are slowly accepting the new realities of law practice. They are starting to figure out how they can do more to prepare their students for it and best assist them in securing legal employment after graduation. There seems to be a consensus that they must "enhance[] the development of professional expertise." ${ }^{50}$ Yet, law schools have taken varying approaches to achieving this goal. Some have begun by introducing intersession offerings and expanding their clinical and externship opportunities while others are requiring more writing across the curriculum or offering more courses that focus on the business of law. ${ }^{51}$

Still others have made remarkable changes to their legal writing programs. Specifically, many law schools with top-ranked legal writing programs require additional practice-writing for graduation. ${ }^{52}$ The rationale is that another sequence of legal writing in the second-year gives students more opportunities to become proficient in advanced legal research and writing. ${ }^{53}$

Schools are also reevaluating what they teach in their mandatory first-year legal writing courses. For instance, law schools are increasingly moving away from the practice of using a single lengthy graded assignment each semester in favor of a series of shorter, targeted, graded assignments, each of which incorporates elements of problem-solving. ${ }^{54}$ Practically, the major writing assignments are much less relevant in today's legal practice. ${ }^{55}$ Young attorneys are more likely to get quick turnaround projects that are more informal and much shorter in length. ${ }^{56}$ They are also more likely to be responsible for writing documents other than an inter-office memorandum and an appellate brief, such as discussion sections of memos, client letters, intra-

50 Michael M. Martin and Ian Weinstein, Harmonizing the Forces Buffeting the Legal Profession, 85 N.Y. St. B.A. J., Sept. 2013, at 58, 60 (urging that an "academic approach to law can and should take practice and the profession of law seriously").

51 Id. For example, beginning in 2015, St. John's University School of Law will require first-year law students to take a January intersession course in Lawyering. See St. John's Law Expands Intersession Offerings, January 16, 2014, available at http://www.stjohns.edu/about/news/2014-01-16/st-johnslaw-expands-intersession-offerings (9.11.2014).

52 For example, John Marshall School of Law, whose legal writing program was ranked \#2 in the 2014 US News Law School Rankings, requires four semesters of practice-writing. See http://www.jmls.edu/ academics/lawyering-skills/ (9.11.2014).

53 Johanna K.P. Dennis, The Renaissance Road: Redesigning The Legal Writing Instructional Model, 38 S.U. L. Rev. 123, 156-57 (2010-2011) (arguing that law schools should adopt a required three-semester system of legal writing).

54 See Responses to Posting of Patricia Grande Montana, grandep@stjohns.edu, to 1rwprof1@list.iupui.edu (April 8, 2013) (on file with author) (soliciting information on required assignments in first-year legal writing courses).

55 Kristen K. Robbins-Tiscione, Ding Dong! The Memo is dead. Which old Memo? The Traditional Memo. 25:1 Second Draft 6, 6 (Spring 2011) (“[T]he traditional legal memorandum is no longer the quintessential form of communication between lawyer and client.”).

56 See id.; see also Kristen K. Robbins-Tiscione, The Rhetoric of Email in Law Practice, 92 Or. L. Rev. 101,118-19 (2013) (arguing that legal writing should teach students to recognize the rhetorical differences between traditional memoranda and email and allow students to practice both). 
office email reports, brief points, letter briefs, and summaries of arguments. ${ }^{57}$ A program that assigns many different types of concise, focused writing assignments will allow students to be strong practice-ready writers in all contexts, not just in one or two. Hence, they will be more flexible in their approach to research and writing and, consequently, more adaptable to the varied needs of legal employers.

Beyond legal writing, law schools have begun "to focus on the transition to practice with incubator and mentoring programs" that bring together practitioners and law students in all different ways. ${ }^{58}$ Practitioners have become more involved in career development activities and, in many cases, integral to the teaching of practice-oriented and specialized courses. ${ }^{59}$ In a break from tradition, law schools are even recruiting candidates from the profession, rather than academia, to lead their institutions. ${ }^{60}$ Law schools are expecting that these closer ties to the legal profession will impact positively on the curricula and job prospects for their students.

Some law schools have made significant changes to what they teach in the second and third year as well. By and large, they have revamped their upper-level curricula to require more simulated and actual practice experiences. ${ }^{61}$ Washington and Lee University School of Law probably has undergone the most dramatic reform to date. ${ }^{62}$ In early 2008 , the law school overhauled its third-year curriculum to be entirely experiential in nature. ${ }^{63}$

Washington and Lee's program notwithstanding, law schools must do more in this regard. Though there are many more clinical offerings and related initiatives than when the recession began, they are rarely mandatory. ${ }^{64}$ Thus, a majority of students still graduate without an experiential experience ${ }^{65}$ or training in leadership skills, the business of law, and other practice-oriented topics. ${ }^{66}$ Regularly neglected topics include problem solving, marketing, practice and project management, interpersonal dynamics, organizational behavior, and information technology. ${ }^{67}$ Knowledge in all of these areas is central to a law student's success in the new legal market.

57 See Kristen K. Robbins-Tiscione, The Rhetoric of Email in Law Practice, 92 Or. L. Rev. 101, 118-19 (2013).

58 Martin \& Weinstein, supra n. 50, at 60.

59 Moliterno, supra n. 30, at 429.

60 Bronner, supra n. 12, at A11.

61 See, e.g., Peter Lattman, N.Y.U. Law Plans Overhaul of Students' Third Year, N.Y. Times, Oct. 16, 2012, at B1.

62 Littman, supra n. 14, at 31; see also Maulik Shah, The Legal Education Bubble: How Law Schools Should Respond to Changes in the Legal Market, 23 Geo. J. Legal Ethics 843, 857-58 (2010) (arguing that law schools need to change their model to allow for more practical training and exploring Washington and Lee's experiential third-year program as one such option).

63 Littman, supra n. 13, at 31.

64 Rhode, supra n. 14, at 448.

65 Id. (explaining how only $3 \%$ of law schools require clinical training, and a majority of students graduate without it.).

66 Id. at 448-49.

67 Id. 
The reality is that students must know much more to be relevant in today's legal market. They must "understand how projects are managed [and] be creative in their view not only of legal analysis but also of business, markets, and the needs of clients." ${ }^{68}$ They need to "take ownership of client problems, be willing to be 'out there' and not merely answer posed questions, and be able to solve problems with ingenuity and creativity." ${ }^{69}$ In short, they need to "acquire the sensibilities of successful lawyers. 70

Additionally, law students need to write better. One of the top complaints from lawyers is that new attorneys cannot write well. ${ }^{71}$ They complain not just about the quality of their legal writing, but also about their misuse of grammar, spelling, and punctuation and inability to follow basic rules on organization and sentence and paragraph structure. ${ }^{72}$ Thus, in order to be competitive, law students must learn to write with greater accuracy, brevity, and clarity. And, their legal analysis must be logical and well-supported. In other words, "[t]hey must be able to answer a given question or make a concrete recommendation that makes practical and realistic sense for the client." 73 Additionally, they must be able to present a clear and compelling argument that appeals to a court's sense of fairness and justice.

One way to teach more practical skills and cultivate this type of good legal writing is through advanced legal writing courses that simulate a "sophisticated, practicesetting." 74

\section{E. Rethinking the Role of Advanced Legal Writing Courses}

\section{Traditional Advanced Writing Courses}

The traditional advanced legal writing course builds on the foundational principles learned in the first-year legal writing program and introduces students to new and more sophisticated types of writing in different practice contexts. These courses can generally be divided into two categories: (1) advanced legal research, analysis, and writing classes and (2) legal drafting classes. In the first category, students develop expertise in complex and lengthy legal research, analysis, and practice-writing. They might be assigned the same types of documents as in the first year or new ones or a combination of both. In all instances, however, the students are explaining how a body of legal authority applies to a specific fact situation. ${ }^{75}$

68 Moliterno, supra n. 30, at 430.

69 Id.

70 Id.

71 Littman, supra n. 9, at 23.

72 Id.

73 Littman, supra n. 13, at 37.

74 Moliterno, supra n. 30, at 434 (employing law schools to do "far more" in the third year).

75 Professor Michael R. Smith has referred to this type of writing as application analysis writing. See Michael R. Smith, Alternative Substantive Approaches to Advanced Legal Writing Courses, 54 J. Legal. Educ. 119, 123 (March 2004). 
In the legal drafting courses, students learn essential drafting and transactional skills and master a variety of transactions. "The primary function of legal drafting is to produce a document that both reflects and yields a client's desired results in connection with some event that is meaningful under the law." ${ }^{76}$ Therefore, students learn that precision in word choice is key, as these documents will often be scrutinized in the future by lawyers, judges, and other audiences. ${ }^{77}$

\section{The Value of Advanced Legal Writing Courses}

In both types of courses, however, the objective is to teach students to be good legal writers. This requires that they be able to solve legal problems for their clients and write documents that are not only "mechanically well-written", but also effective at achieving their desired results. ${ }^{78}$ Good legal writing is essential for the successful practice of law. "Good legal writing is valued in law practice, however, not only because it is indicative of the writer's ability to communicate effectively, but also because it is indicative of the lawyer's overall practice competence."79 "Put simply, good legal writing is reciprocal to good lawyering. ${ }^{80}$ Accordingly, advanced legal writing courses present an excellent means to teach students to be good lawyers. While they certainly cannot expose students to every challenge they will face in legal practice, they can provide "more opportunities for students to integrate theory and practice in meaningful ways and to learn processes for acquiring new knowledge." 81 "The process of writing legal documents in law school necessarily provides students with an early opportunity to integrate theory and practice. Through the process of writing, students apply and stretch their knowledge of law." 82

The experience can be further enhanced by mimicking the realities of law practice and challenging students to complete tasks as a practicing attorney would. ${ }^{83}$ Through a simulated law practice, not only do students perform the important processes of fact investigation, problem-solving, research, and writing, but they also engage in the strategic and professional decisions that are implicated by those processes.

\section{A More Modern Approach to Advanced Legal Writing Courses}

A more modern approach to advanced legal writing courses goes beyond the basic teaching of more in-depth or different genres of legal writing. It infuses reality into the classroom by simulating legal practice. It ties all of the assignments into a single

76 Id. at 124.

77 Id. at 125 .

78 Keene, supra n. 11.

79 Id.

80 Id.

81 Id.

82 Id. In fact, "[g]uided legal writing practice experiences (real or simulated) afford the writer a meaningful opportunity to integrate theory and practice by using her knowledge of law to identify and solve a range of discrete legal problems while acting in the attorney role." Id.

83 Id. 
problem which the students then work on as if they were real lawyers on the case. ${ }^{84}$ It uses real-world problems for assignments, ones that reflect what is current and relevant in a particular practice area. These types of authentic learning tasks, as called by constructivism learning theorists, promote active learning. ${ }^{85}$ Indeed, " [s]tudents respond best to assignments that they perceive to be grounded in reality, having some sense of reality and possible importance." 86

In order to approximate a real case, the parties, witnesses, and other actors are welldeveloped and have rich personalities and diverse characteristics of real people. There is also an extensive hypothetical record with factual complexity and indeterminacy. The problem is not artificially balanced or highly controlled; there are ambiguous or unknown facts as well as facts that clearly favor or harm one side. ${ }^{87}$ The uncertainty challenges the students to exercise judgment and the definite favorable and unfavorable facts provides a "reasonable basis" for "exercising [that] judgment." 88

It also assigns a series of tasks that are representative of what lawyers encounter in their everyday practice. In addition to factual investigations, research, problem-solving, and writing, the students must consider the real-world implications of their decisions. For every task, they must consider their trial tactics and strategy, the likely outcome, their client's interests, the risks and costs, professional ethics, and other practical factors. They perform formal tasks, like drafting pleadings, responding to discovery requests, and writing motion briefs. They perform less formal tasks as well, like drafting demand letters, summarizing meetings with clients, digesting deposition testimony, prepping for phone calls, and writing emails or letters to opposing counsel and clients.

An effective simulation covers a single substantive area of law. Though there might be different procedural issues that arise throughout the course, the subject matter would be the same. In this way, the students can gain a solid understanding of a discrete substantive area of the law. This would "give students a richer opportunity to develop their analytical and other skills while learning the fine points of a specific

84 Professor Kenneth D. Chestek refers to this as the "moot case" approach to teaching legal writing. See Kenneth D. Chestek, Reality Programming Meets LRW: The Moot Case Approach to Teaching in the First Year, 38 Gonz. L. Rev. 57 (2002-2003).

85 Susan E. Thrower, Teaching Legal Writing Through Subject-Matter Specialties: A Reconception of Writing Across the Curriculum, 13 J. Legal Writing 3, 19-21 (2007) (explaining how DePaul University College of Law offers, in addition to general legal writing sections, specialized first-year legal writing sections, to which students interested in that particular specialty may apply).

86 Id. at 21 .

87 While it is true that "simulation cannot approximate the greater factual richness and uncertainty introduced by real cases," when done correctly, it is an effective alternative to actual legal work, as not all instruction can be done in a live setting. See Michael A. Millemann and Steven D. Schwinn, Teaching Legal Research and Writing with Actual Legal Work: Extending Clinical Legal Education Into the First Year, 12 Clinical L. Rev. 441, 456-57 (2005-2006) (arguing that legal research and writing teachers should use actual legal work in their courses as it allows them "to engage students fully, teach core LRW skills effectively, introduce students to professional responsibility and accessto-justice issues, and provide legal help to unrepresented and under-represented clients).

88 Jay M. Feinman, Simulations: An Introduction, 45 J. Legal Educ. 469, 473-74 (1995). 
area of law." 89 Though the problem should be factually complex, it should not be legally complex..$^{90}$ The area of law should be accessible to the students; it should be well-settled, uniform, and relatively straightforward. In short, the students should be able to easily understand and apply the relevant legal principles to their case.

Ideally, the course would follow a curriculum in which the students represented a single client and worked exclusively on that client's case for the entire semester. ${ }^{91}$ Students would be assigned a range of projects similar to those given to junior associates, "though with a compressed timeline so all the work could be completed within the semester." 92 Preferably, the students would work on the case from inception to the end, that is, until at least a decision on the merits. "By engaging in the actual process of developing a case from its inception, the students ... work actively with the material, and thereby learn more easily the skills they will need in the actual practice of law." 93 They also "gain a sense of ownership of the problem, which translates into a better understanding of the issues involved and better writing and oral advocacy." " Finally, they can "see immediately why research and writing skills are necessary and how they are used to solve problems in the 'real world' of practicing law." 95

Though the course should "simulate the tasks and speed characteristic of the law office environment," it should also "provide the academic opportunity for feedback, editing, and reflective learning, for learning and mastering the process of writing." 96 There should be different writing experiences and plenty of opportunities for students to revise and rewrite. The students also should give and receive peer feedback. And, importantly, the students should have a chance to reflect on each experience. ${ }^{97}$ Continuous student feedback and reflection will ensure that this more modern approach to an advanced legal writing course will be successful.

89 Susan L. DeJarnatt, In re MacCrate: Using Consumer Bankruptcy as a Context for Learning in Advanced Legal Writing, 50 J. Legal Educ. 50, 56 (2000) (explaining the design of a course that uses a simulated case file from Chapter 7 Consumer Bankruptcy law to develop students lawyering skills while at the same time teaching the substantive law).

90 See Chestek, supra n. 84, at 84 .

91 See Judith Rosenbaum, Brutal Choices in Curricular Design... New Directions in Advanced Legal Writing Courses, 19 Perspectives: Teaching Legal Res. \& Writing 134, 136 (2011) (describing how Northwestern University School of Law's advanced legal communication course is centered on a single case file for a single client).

92 Id. at 136.

93 Chestek, supra n. 84, at 62.

94 Id. at 63.

95 Id. at 62.

96 DeJarnatt, supra n. 89, at 55-56.

97 Chestek, supra n. 84, at 83. 


\section{Simulating Complex Litigation}

My own advanced legal writing course, Drafting: Federal Civil Practice, ${ }^{98}$ simulates a complex litigation in federal court. The course is not only designed to give students experience in drafting the legal papers necessary to prosecute a civil action in federal court, including pleadings, discovery requests, and non-dispositive and dispositive motions, but also to immerse students in the everyday practice of law. Students are asked to imagine that they work as junior attorneys in a small law practice as they tackle the research and writing assignments and other tasks that their representation entails.

The entire course is tied to a single case involving a same-sex claim of workplace sexual harassment under Title VII of the Civil Rights Act of 1964. The students take up the case in the pre-litigation phase and follow it through discovery and motion briefing, to the final phase, an opposition to a motion for summary judgment. All of the students represent the same side - the plaintiff - and do so for the entire semester.

\section{The Subject Matter}

Title VII cases are well-suited for this type of simulation because they present interesting and challenging issues, without being overly complex or too vague. A sexually hostile work environment claim has four distinct elements. They can be summarized as follows: (1) the plaintiff was subjected to unwelcome sexual conduct; (2) the conduct was severe or pervasive; (3) the conduct was directed at the plaintiff because of his sex; and (4) there is a basis for employer liability. ${ }^{99}$ What's nice about a statutory problem like this is that there is much flexibility in how difficult and intricate you can make each element.

In most cases, however, the first element is almost always undisputed, as it requires mainly a subjective analysis of whether the conduct was unwelcome. The last element —employer liability — can be made undisputed as well if supervisors are the ones harassing the plaintiff, as employers are vicariously liable for acts of their supervisors, even in the absence of any notice or knowledge. ${ }^{100}$ Here is where you could create sub-issues; you could make it debatable as to whether the harassers had the requisite degree of control over the employee to be considered "supervisors" under the applicable law. Or, you could raise the question of whether the employer is entitled to raise an affirmative defense. Even in cases of vicarious liability, an employer can raise such a defense if it took no tangible employment action, defined as a "significant change in employment status, such as hiring, firing, failing to promote,

98 It is a one-semester 2 credit elective open to 20 second- or third-year students. Though the course itself is not required, at St. John's University School of Law, students are required to satisfy an advanced practice writing requirement (the "APWR") in either their second or third year. My course is one of over 30 courses that satisfy the APWR.

9942 U.S.C. $\mathbb{S} 2000 \mathrm{e}-2(\mathrm{a})(1)$; Harris v. Forklift Sys., Inc., 510 U.S. 17 (1993).

100 Burlington Indus., Inc. v. Ellerth, 524 U.S. 742 (1998); Faragher v. City of Boca Raton, 524 U.S. 775 (1998). 
reassignment with significantly different responsibilities, or a decision causing a significant change in benefits." 101

To prevail on the affirmative defense, the employer must establish two prongs: (1) the employer "exercised reasonable care to prevent and correct promptly any sexually harassing behavior," and (b) the employee "unreasonably failed to take advantage of any preventive or corrective opportunities provided by the employer or to avoid harm otherwise." 102 Though these prongs are straightforward, rebutting the defense requires significantly more research and analysis and additional argument. If you want this greater depth, all you need to do is make clear that the plaintiff's employment status was unaffected by the conduct.

Nonetheless, in the absence of such sub-issues, the second and third elements are usually the most disputed and therefore need the greatest rule development. The students must grapple with explaining when conduct crosses the line of boorish behavior and becomes actionable sexual harassment. They must also use the United States Supreme Court's guidance in Oncale - the decision that recognized that samesex sexual harassment is actionable - to establish the "because of sex" element when the harassment occurs between members of the same sex. ${ }^{103}$ The Court outlines three possible evidentiary routes for proving this element. ${ }^{104}$ Since discrimination, however, cannot be reduced to a rigid formula, these routes are merely illustrative, and not exhaustive. ${ }^{105}$ Thus, there is ample room to raise competing arguments. There is also room to introduce arguments that do neatly follow one of the outlined methods, thereby forcing students to think creatively and present novel arguments. For example, some courts have recognized the failure to conform to gender norms as a cognizable claim of gender discrimination under Title VII, even though discrimination based on sexual orientation is not allowable. ${ }^{106}$ The fact that there is such incongruity in the law makes this such a fascinating case to litigate. A single fact can take on multiple meanings. And, an argument on one method can easily contradict an argument on another. Therefore, students are faced with considerable litigation decisions that directly impact their writing and presentation of the case.

Thus, Title VII issues have real pedagogical advantages to using them. They are distinct enough that they can be segregated and assigned in different stages with their

101 Ellerth, 524 U.S. at 761.

102 Id. at 765.

103 See Oncale v. Sundowner Offshore Servs., Inc., 523 U.S. 75 (1998).

104 Id. at 80-81. In order to support a same-sex harassment claim, the plaintiff must show that the conduct at issue "was not merely tinged with offensive sexual connotations, but that it constituted 'discrimination because of sex.'” Id. To do this, the plaintiff must offer "credible evidence" that the harasser was a homosexual and made sexual advances to others or intended to have some kind of sexual contact with the plaintiff; or evidence that the plaintiff was harassed in such sex-specific and derogatory terms as to make it clear that the harasser was motivated by a "general hostility to the presence of the other sex in the workplace"; or "direct comparative evidence" about how the harasser treated members of both sexes in a mixed-sex workplace. Id.

105 Id.

106 See, e.g., Dawson v. Bumble \& Bumble, 398 F.3d 211 (2d Cir. 2005); Simonton v. Runyon, 232 F. 3d 33 (2d Cir. 2000). 
own corresponding research and writing assignments. An element like employer liability can involve more intricate discussions if you create sub-issues. And, the "because of sex" element can be more nuanced if you present facts that fall outside the scope of the three outlined evidentiary routes. Once the elements, sub-issues or not, are brought together, the students have the opportunity to work on a very advanced and sophisticated piece of writing. The benefit of multi-issue problems is that students must wrestle with real questions over organization, presentation, and style and draft an effective thesis that connects all points.

What's more, these types of cases are so fact-specific that you are able to develop a very rich record and create actors with multifaceted personalities and diverse experiences. You also do not have to account for every fact, as ambiguity can be addressed easily in the analysis. For example, in deciding whether conduct is severe or pervasive, courts look at "all of the circumstances"; no one factor is dispositive. ${ }^{107}$ Therefore, essentially any fact, slight or not, can be factored into the analysis.

\section{The Design}

The class is designed to simulate how a case evolves and to present the myriad of activities a practicing attorney might handle as the case is ultimately litigated in federal court. This means any information about the case, including all facts, is revealed to the students in stages, "akin to the development of a real case." 108 Therefore, when they first learn about the plaintiff's problem, they are not told much, as the "supervising attorney" on the matter at the time has only spoken briefly with the plaintiff. In their first assignment, the students are given the following limited factual background:

The client, Anthony Russo, a young and talented baker, alleges that he was subjected to a hostile work environment stemming from the conduct of his male supervisors. Mr. Russo was a cake decorator at the well-renowned Carlo's Bake Shop in midtown Manhattan. He alleges he repeatedly told management that he was being sexually harassed, but they never took his complaints seriously. As a result of the harassment, he claims that he was forced to quit. He has been unable to find another job. He wants to know whether he can sue for his injuries.

As you can see, the details of the plaintiff's claim have not been included. The first assignment, which must be completed before the first class, asks the students to prepare for their initial meeting with the client. They must begin with the essential task of gathering information. ${ }^{109}$ This task has two aspects: gathering the relevant facts and understanding the law. The first assignment is intended to present both aspects. Thus, they are instructed to read the relevant statutory provision and the Oncale decision, and then brainstorm areas that they would need to address with the client. 
They must understand the claim and its elements before they can choose relevant questions to ask the client.

During the first class, the students exchange their questions and discuss the best way to approach the client interview. Given the nature of the complaint, the students anticipate that there might be some personal, sensitive or emotional parts to the plaintiff's story. We thus discuss how to address that possibility and then role-play several scenarios of the attorney-client meeting. This ends the first phase of the fact gathering process. Before the next meeting, the students will receive a "memo to the file" written by another junior attorney. The students are asked to imagine that they met with the client on several occasions. The memo itself summarizes what facts they gathered in those meetings.

With this memo, the students have more background on the plaintiff's discrimination charge and some details with which to now work. At this point, the students are directed to do some additional research and begin preparing a complaint. The students quickly realize that research, like writing, is not a linear process. New facts might mean additional research and any new information they learn about the law might translate into additional fact gathering. After the students go back and forth a few times and learn several more details of the case, they begin to draft the complaint.

As part of a complaint drafting exercise, the students must resolve all jurisdictional and conditions precedent questions. They also must decide whether to plead beyond the notice requirement of Rule 8 of the Federal Rules of Civil Procedure. They must balance, for example, the desire to tell a compelling story with the risk of prematurely committing to a specific version of events. Soon after completing the complaint, the students receive the defendant's responsive pleading, an answer, in which the defendant-employer denies all of the substantive allegations and raises the affirmative defense. The students are then asked to articulate the defendant's theory of the case and predict what will likely be the most hotly contested issues.

The next phase of the litigation is discovery. The students learn about the various discovery methods under the Federal Rules of Civil Procedure and use some of the more common discovery tools to obtain support for their case. The students draft identification and contention interrogatories, requests for admissions, and document requests. They also decide on which people they should depose. An interesting feature of the discovery rules is that they provide considerable detail about how each tool should be used but not much about how they should be used together. There is no order for when to submit interrogatories, document requests, or deposition notices, for example. Thus, the order in which to use the tools is based on the needs of the individual case and the experience of the lawyers. The students play with the relationship between them and the timing as they work out their strategy for discovery. At this time, the students receive a small production of documents, including several emails and texts, in which the client refers to the conduct as "teasing," and an employment manual that explicitly proscribes sexual harassment. 
Eventually, the students are given the defendant's objection and response to a single document request that seeks all documents relating to prior allegations or complaints of discrimination against the defendant. In short, the defendant agrees to produce only those non-privileged documents relating to the plaintiff's complaint of discrimination. This sets the stage for a discovery dispute. The students recognize the value of having information about others' discrimination complaints. Yet it becomes even more essential after the students learn that other employees had, in fact, complained about harassing comments made by the same supervisors. Through the discovery phase of the class, the students receive deposition testimony in digest form. The past instances of harassment are revealed in one of the digested depositions.

The students thus write a letter to opposing counsel demanding that the defendant produce all documents, not just those related to the plaintiff's case. The students assess audience, tone, formal writing, etc. They are given poor and good examples of each to make these determinations clearer. Then, the students are finally given the defendant's final response. The defendant is unwillingly to waiver on its position. After conferring in good faith, as required by the Federal Rules of Civil Procedure, the students are ready to move to compel the production of the documents.

Accordingly, the next stage in the litigation is motion practice. The students prepare the motion papers. Most importantly, they write a memorandum of law in support of the motion. The students orally present their arguments in class as well. The motion entails three arguments, namely that the documents are relevant, the request is neither overly broad nor unduly burdensome, and there is no countervailing confidentiality concern. Even though this is a discovery motion, it provides another opportunity to sensitize the court to the merits of the case. Therefore, students carefully consider how to give substantive context to their legal arguments.

The students are pleased when the court issues an order in their favor and mandates that the defendant produce all of the requested, non-privileged documents. At the same time, the students receive a small production. It includes notes from the human resources department. Those notes reveal that there were two possible other instances of harassment. Neither instance is analogous to the plaintiff's case, however. One involves a female server claiming that the supervisors favored the males and the other involves an African-American cashier, who overheard the supervisors tell racially offensive jokes. Though helpful in showing that the environment at the bake shop was generally hostile, neither fully bolsters the plaintiff's claim.

The last phase of the litigation is the summary judgment phase. Here, atypical for a legal writing class, the students are given their opponent's brief. In the case, it is the defendant who has moved for summary judgment on the Title VII claim. The students receive the defendant's memorandum of law in support of its motion. The students first work on dissecting the brief through guided worksheets. Then they work on responding to the brief. The students must bring together the entire semester's worth of work to write an effective response. Ultimately, the students write a first draft and then a re-write of the argument, which turns out to be approximately 
20 pages in length. Because this motion has the potential to dispose of the case, it is a natural place to end the course. Though the students do not receive an actual decision by the court, as it is their last writing assignment of the semester, they quickly get a sense for how to frame and argue a strong case.

\section{The Method}

The class lends itself to a number of learner-focused teaching methodologies. Students are naturally more engaged in the material when they are active in their learning. Therefore, there is limited lecture or Socratic dialogue in the class. Most of the discussion is developed organically through critiques and evaluations of the documents or through collaborative efforts. The most collaboration occurs in the brainstorming and pre-writing stages of assignments. For instance, the students work together on developing questions to ask the client in the attorney-client interviews and the witnesses in the discovery phase of the case. The students also collaborate in deciding what allegations to include in the pleading and what types of interrogatories to ask and documents to demand. Critical to the writing process, students work in groups to decide on the large-scale and small-scale organization of both briefs.

Students also work on many in-class writing exercises throughout. After looking at a model together, the students are usually given time to write on their own. Oftentimes, I will give the students guided worksheets--worksheets that guide them through the writing process in a very organized and intentional way. These guided worksheets are most helpful when analyzing the defendant's brief in support of its motion for summary judgment. We dissect every aspect of the argument so that they can decide how best to respond. The students then use another guided worksheet to help them build their responsive arguments.

There are many opportunities for the students to revise their writing as well. Every graded writing assignment has multiple drafts, the last of which is the only one graded. Because research and writing is such a recursive process and attorneys continually revise their own work, both are built into the course.

Furthermore, the class heavily relies on peer critiques to improve the students' analysis and writing. Almost all of the writing assignments have a peer critique component. The students are asked to evaluate each other's drafts using written guidelines on the critiquing criteria. "Through peer review, students improve their legal analysis and writing, enhance their editing skills, learn to cooperate with others, manage and evaluate constructive criticism, and develop a deeper appreciation of audience, among other things." 110 It is also an effective way for [professors] to give additional, and more continuous, feedback on their students' performance. ${ }^{111}$

Finally, there are oral presentations and role-playing throughout as well. For example, the students act out the attorney-client interview, a telephone conversation with

110 Patricia Grande Montana, Peer Review Across the Curriculum, 91 Or. L. Rev. 783, 785 (2013).

111 Id. 
opposing counsel, a conference with the court, and an oral argument on the motion for summary judgment. Needless to say, the class is a very dynamic one. Students must participate in every way in order to successfully prosecute the case in federal court.

\section{The Benefits of the Simulation Model}

The simulation model for teaching an advanced legal writing class is an excellent way to get students "practice ready." "Not only do the students get a glimpse of what life as a lawyer is really like, they get to try on the role of being a lawyer in order to see how they might fit into the profession." 112 Legal disputes are given context and brought to life as the students must navigate the case from its beginning to end. They must "integrate different bodies of knowledge and . . . apply legal reasoning and problem-solving abilities to a complex situation." 113 They become intently aware of their ethical and professional obligations to clients, other parties, and the court. They become extremely familiar with court rules and customs too.

Moreover, the students learn to deal with the opposing side. At every stage, the students must anticipate their opponent's position and test their own work for consequences. Through this process, "[t]hey discover that the other side has legitimate arguments, and that cases in progress are rarely as black and white as the final decisions sometimes make them appear to be." 114 They also learn to treat opposing counsel with civility. ${ }^{115}$

"A ... richly textured course" that recreates a real case unfolding over time "increases students' interest, because it seems more relevant and more real to them." 116 "When they feel like lawyers—rather than just students—-they invest more of themselves in their work." 117 Further, when students develop a connection with a client, as they do in simulations, they become invested in the case and, as a result, more active in their learning. The relationship with the client also "ma[kes] it easier for the students to make informed distinctions between legally-relevant facts, emotionally-appealing facts, and wholly-irrelevant facts." 118 Additionally, because they represent a single client with a sympathetic claim, "[t] hey can see how a client's emotional involvement influences strategic decisions." 119 The shared experience also results in increased student cooperation and collaboration. Students learn tremendously from their collaborative efforts and peer critiques. ${ }^{120}$ The additional feedback helps to improve and hone their research and writing skills as well.

112 Chestek, supra n. 84, at 70.

113 Feinman, supra n. 88, at 472.

114 Chestek, supra n. 84, at 71 .

115 Id. at 73.

116 Thrower, supra n. 85, at 39.

117 Id.

118 Chestek, supra n. 84, at 72 .

119 Id. at 71.

120 Id. at 73. 
Obviously, writing is at the core of any advanced legal writing course. The benefit of a simulation is that their writing has context. As adult learning theory submits, students "learn best if they have a context for what they are learning." 121 The students are able to write with a purpose and have numerous opportunities to revise and rewrite. The intensive writing experience coupled with continual guidance and feedback "encourages law students to reflect on their professional judgments and consider the choices they will make in the future" as practicing attorneys. ${ }^{122}$ Thus, the simulation model prepares students in all respects. Accordingly, "they get a head start on bridging the gap between law school and practice." 123

\section{F. Conclusion}

An advanced legal writing course that simulates a complex litigation practice can be part of any law school's solution to preparing more "practice ready" lawyers. "If law schools consider legal writing for what it is, a unique opportunity for students to not only improve their writing, but also build practice competence, it is easy to see how further legal writing practice can help bridge the gap between legal education and practice by providing these opportunities." 124 Thus, law schools should move now to integrate simulation experiences into their advanced legal writing courses.

121 Deborah Maranville, Passion, Context, and Lawyering Skills: Choosing Among Simulated and Real Clinical Experiences, 7 Clinical L. Rev. 123, 128 (2000-2001).

122 Keene, supra n. 11.

123 Chestek, supra n. 84, at 71.

124 Keene, supra n. 11. 